\title{
The Political Economy of Civil Service Pay in China: A Panel Data Analysis
}

\author{
Yu You $^{1} \cdot$ Guang Zhang ${ }^{1}$
}

Received: 29 October 2015/Accepted: 14 March 2016/Published online: 5 April 2016

(C) Fudan University and Springer Science+Business Media Singapore 2016

\begin{abstract}
How does the Chinese government pay its officials in different regions? What determines regional variation in civil service pay? These are important questions for understanding the Chinese government. We argue that regional difference of civil service pay is shaped by both political and economic factors. After review of policy changes in government salaries since the $1950 \mathrm{~s}$, we conduct an empirical analysis using a panel of 31 provinces from 1997 to 2008. The results indicate that, fiscal transfers, local and self-raised revenues significantly raise wage levels across provinces under certain conditions of government size. Furthermore, Civil service pay positively correlates with level of regional economic development, and also, according to a certain base, central policy of wage adjustment accelerates the rate of increase in civil service remuneration.
\end{abstract}

Keywords Civil service pay - Wage policy regulation - Cross-provincial variation · Intergovernmental fiscal relations

\section{Introduction}

What determines cross-provincial difference in civil service pay in China? This is an intriguing and important, but systematically unanswered question. In this paper, we attempt to uncover the determinants of the variation in civil service pay across Chinese provinces through panel data. Judging by numbers, civil service pay has been a contributing factor in increasing inequality of regional income since the

Yu You

youyu_00@163.com

1 School of Public Affairs, Xiamen University, Xiamen, Fujian, China 
opening up of China. ${ }^{1}$ In 1980, Qinghai, with an average civil servants' salary of 1097 yuan, ranked first among all the provinces in civil service pay. This figure, however, was only $42 \%$ higher than Sichuan, which appeared at the bottom of the list. In 1995, the highest civil servants' pay on average was $116 \%$ higher than the lowest (9005 yuan in Shanghai compared with 4161 yuan in Guizhou) and the figure rose to $177 \%$ in 2012 (90,622 yuan in Shanghai versus 32,672 yuan in Shanxi).

It is worth pointing out that since civil service pay is fully financed by the state's fiscal revenue, adjustment are politically and ethically sensitive, evident during the National People's Congress (NPC) and the Chinese People's Political Consultative Conference (CPPCC). Besides social impact, change in civil service pay system also affects the morale of civil servants, especially for average wage earners in the public sector who are more likely to live better lives with improved compensation (Wu 2014; Child 1995). Obviously, China is not a singular case. After the 2008 financial crisis, public expenditures turned into an age of austerity (Ortiz and Cummins 2013), and many questioned salary levels of the public sector in different countries, especially Europe, so wages and jobs have been cut or frozen, most frequently by unilateral state decision all over Europe (Glassner 2010).

Although the topic has made ripples in society, it has not received sufficient scholarly attention from the field of public administration. From the beginning of this century, Cooke $(2004,895)$ comments in a retrospective study that "despite the quantitative and qualitative significance of the public sector in China, insufficient studies have been carried out to advance our knowledge of its pay policy and practice and any changes that may have taken place in the wake of the market economy". Existing empirical research and policy analysis based on data from qualitative interviews, case studies or statistical yearbooks does offer us some important theoretical perspectives and policy information. ${ }^{2}$ For instance, Chew (1990a, b) and Cooke (2004) focuses on the state-led reforms in China's public sector pay, and analyzes these reforms using the materials from her interviews with her friends in the Chinese academia. Wu $(2009,2011)$ further analyzes the policy reform of government officials' wages and its impact from the perspective of centralization and decentralization in China. As for the popular subject of "paying a good salary to reduce corruption" (Yixin Yanglian), a study by Gong and Wu (2012) demonstrates that high-speed economic growth almost goes hand in hand with serious corruption, and there also exists complicated relationships between the civil service pay system and the construction of a clean government. Chan and Ma (2011) are interested in whether the civil service sector in China pays its employees well or not. By comparing China's civil service salary reform with other developing countries, the authors conclude that the wage level is never low in China. In his recent book, $\mathrm{Wu}$ (2014) makes a detailed discussion about the process of setting the standard of Chinese civil service pay and in doing so, elucidates the interactions

\footnotetext{
1 Many studies discuss increasing urban wage inequality in China since 1978. See, for example, Knight and Song (2003), Kanbur and Zhang (1999), and Yang (1999).

2 See, for example, Chew (1990a, b); Chan and Suizhou (2007); Burns and Wang (2010); and especially Wu (2014).
} 
among different players, providing not only the macro-institutional scenario but also the tug-of-wars among different stakeholders.

Nonetheless, in the discussion and analyses of the national policy of officials' salaries, many existing studies rely on historical narratives or comparisons across countries or professions. Few empirical studies directly focus on the regional differences in civil service pay within China through econometric analysis. This paper attempts to fill this gap, and is structured as follows. First, we provide a unified analytical framework to explain the outcome of interest. Next, we document policy changes in civil service pay since the founding of the People's Republic of China. Then, based on the theoretical framework and related policy changes, we put forward explanatory variables and formulate a number of hypotheses to be tested. Finally, we present our data, model specification and findings, followed by some concluding comments and policy suggestions.

\section{Explaining the Regional Variation in Civil Service Pay: A Theoretical Framework}

Loads of studies have shown that income of laborers and its disparity are jointly determined by market (economic) and political factors (Beramendi and Cusack 2009; Erickson and Ichino 1995; Soskice 1990). The same can also be said about salaries of civil servants. However, since civil servants' remuneration is directly financed by tax revenue, it is more sensitive to political factors than other sectors such as manufacturing and construction industries.

In general, wages paid to workers mainly adjust through the supply-demand relationship of labor. Theoretically, an increase in workers within a sector raises the supply of labor and the wage falls. On the other hand, holding labor supply constant, the income level would rise as demand for labor increases. In fact, level of economic development is a crucial determinant of the regional variation in income. Growth in economy, which always translates into higher labor demand and living cost, drives up the income level. Existing studies have also found that income level is higher where the market is more animated, since corporations are most likely to invest and operate in these locations. Higher density of commercial activities means higher demand for workers, which pushes up the wage level (Hering and Poncet 2010).

Since civil service is deeply embedded in "central planning", the government largely controls the supply-demand relationship of civil servants. As classical theoretical literature of public choice goes, as economically rational actors, bureaucrats pursue to maximize budget and to expand government size (Niskanen 1971; Brennan and Buchanan 1980). In a modern society, however, the enlargement of government is also conditioned by a number of economic factors and public opinion. Economic elements affect civil service pay by "setting" certain economic fundamentals that constrain acts of government. The most important factor is economic development. Supported by public finance, civil servants' remuneration ultimately comes from all kinds of economic entities where the government draws fiscal revenue to maintain its operation. As can be expected, to a certain degree, 
higher level of economic development means less restrictions imposed on the government to pay its employees. Meanwhile, higher level of economic development raises the demand for labor and better skills in the public sector, and thus improves civil servants' remuneration. The second factor is living cost, which is closely related to economic development. Usually, the levels of wage, pension and government subsidy are linked up with the cost-of-living index, which varies a lot across regions $^{3}$ (Boskin et al. 1998; Boskin 2008). In fact, for many sectors, the living cost subsidies are annually adjusted based on the updated living cost index of the region, and civil service is not an exception. Besides, in a market-oriented economy, Tiebout's (1956) theory of "voting with feet" easily extends from "electorate" to "capital", meaning that relatively free-flow capital would select destinations that could best satisfy its demands, which in reverse influences government performance. Civil servants' wages in all regions constitute the bulk of the government's operation costs, and are eventually paid by the whole society. Thus, the operational costs and efficiency of the government, too, need to be accountable to capital competition. Since the level of urbanization and industrial structure are imbedded in the local economic ecology, they may potentially affect local income level as well.

Compared with economic factors, political elements-especially intergovernmental relationship-have a more immediate impact on the civil service pay in different regions. In order to simplify the reasoning, it is assumed that there are only central and local governments. Theoretically, civil service remuneration within a nation is determined by one of the three mechanisms: (1) entirely decided by the central government; (2) absolutely autonomously decided by local governments; (3) jointly decided by the central and local governments. Countries with centrally planned economies, such as the Soviet Union and P. R. China before its reform and opening up closely proximate the first mechanism, while those highly decentralized federal states like the United States of America are much nearer to the second one. However, most countries, including P. R. China after 1982, belong to the third category. Central government may control local income level by two means: policy regulation and fiscal appropriation. In highly centrally planned economies, the central government could stipulate the income levels of civil servants (generally including enterprise staff) and the classification of regions such that regions with higher living cost are given higher local subsidy indices).Furthermore, remuneration of local civil servants is wholly derived from fiscal appropriation from the central government. In the third pattern, the central government may still adopt these two measures to affect civil service pay and its regional variation, with fiscal appropriation often called transfer payment in this case. Similarly, in the second and third categories, the local government still has these two devices (policy regulation and fiscal appropriation) to exert an impact, but there is little doubt that the latter is more significant. In general, the more financial resources a local government possesses, depending on local economic development and financial capability of the government, the higher civil service remuneration would be.

\footnotetext{
3 A common example is the Consumer Price Index.
} 


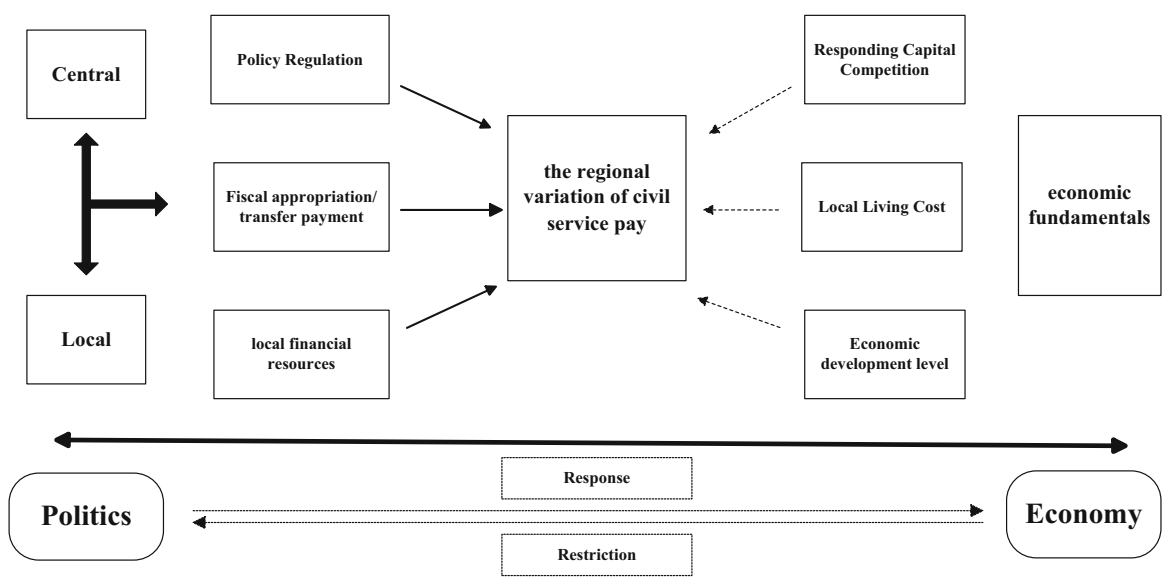

Fig. 1 The theoretical framework. Data source: Made by the author. Solid arrows indicate direct effects, while dotted arrows show indirect effects

In conclusion, income level of local civil servants and its regional variation within a nation are the outcomes of the interaction between politics (for example, inter-governmental relationship) and its domestic economic fundamentals. ${ }^{4}$ The political dynamic works through the interaction between the central and local governments, using policy regulation and fiscal appropriation (including transfer payment). This interactive relationship of these elements is demonstrated in Fig. 1.

\section{Civil Service Pay in China: An Overview of Policy Changes}

Since the founding of P. R. China, the central government tightly holds onto the power to set wages for each level of civil servants and to make the relevant policies. However, the system does have distinctive differences before and after the reform and opening up. Before 1982, the economic system of China was a centrally planned system, and local governments did no more than implement orders from the center. The center drafted a unified payment system, determined the regional variation within the same remuneration ranking based on the principle of egalitarianism, and afforded fiscal appropriation to finance local wage expenses on the basis of unified state control over income and expenditure (tongshou tongzhi).

Specifically, China implemented a dual track institution of "supply system" and "wage system" for a short period of time from the early days of the Republic to 1956. In August 1956, "Command on All Staff of the State Organs to Implement Wage System and Transfer to Monetary Wage System" (guojia jiguan gongzuo renyuan quanbu shixing gongzizhi he gaixing huobi gongzizhi de mingling) was officially issued by the State Council, with purpose of abolishing the supply system

\footnotetext{
4 This article mainly investigates the role of the key domestic factors in determining civil service pay, rather than the potential international factors affecting the income level of the workforce among various sectors, such as the effects of export or international trade (Araújo and Paz 2014; Sauré and Zoabi 2014).
} 
and carry out wage system reforms. Such reforms were formally put into effect in the following year. Wages of all administrative officials were divided into 30 ranks; and the whole nation was classified into 11 regional categories, taking the living standard and cost variance across regions into account. The first category mainly consisted of the southwestern provinces, and the 11th by and large referred to the northwestern region. Officials' wage of the first regional categories was $30 \%$ higher than that of 11th category in the same rank (Shi and Wu 1993). According to the policy and regulation of 1956, promotion of administrative officials was divided into two types: regular and irregular. In the former case, assessment of wage level was conducted annually, and wage rank was adjusted with promotion. Yet, the wage system launched in 1956 did not come into force due to the national political turmoil, which rendered the annual wage assessment and rank promotion completely unsuccessful. Irregular promotion had only been held four times totally during the period of 1957-1977 among the staff across the nation. On average, the wage level of each staff member advanced for less than one rank. During the same period, the promotion of staff in the central government occurred only three times (Shi and Wu 1993, 213). Government officials' wages not only remained low before the reform, but also had little disparity among various regions, in addition to being almost fully decided by the regional classification made by the center.

After the reform and opening up, China gradually turned to a market economic system, which introduced local decentralization into inter-governmental relationship, giving rise to a situation whereby the central and local governments, together with some economic fundamentals jointly decided the income level of civil servants and its regional variation. As far as civil service reform was concerned, from the 1980s to the promulgation of the new regulations in 1993, and later the passing of the Civil Service Law in 2006, to some extent, more competition, additional monitoring and performance-based rewards were introduced to civil service sector (Burns and Wang 2010). However, compared with other sectors, wage levels of civil servants are still much more strictly controlled by the governments at all levels, especially by the central government. This is clearly shown by the fact that the central government is the only framer and decision maker of the national unified civil service pay system. Like the situation in the planned economy before 1978, the central government is granted the authority to determine basic wage ranks of all civil servants, and the timing of nationwide wage and rank adjustment (tiaozi shengji). However, something has changed since the reform and opening up: the central government has brought in the structural wage system, gradually transferring part of the decision-making power of the civil service pay to local governments. "Reform Scheme of Staff Pay System in National Agencies and Public Institutions" (guojia jiguan he shiye danwei gongzuo renyuan gongzi zhidu gaige fangan) issued by the State Council in 1985 first introduced the structural wage system. The structural wage includes four parts: the basic pay, the headship pay (zhiwu gongzi), the seniority pay and the awards. With exception of a few areas (like some special economic zones), there is little regional variation in the first three components of the wage structure, while the awards are in principle a reward to those who have better performances and the fund almost comes from the administrative budget surplus. Thus, the structural wage system extended some characteristics of performance- 
based pay. Using the structural wage as a starting point, the central leadership in China then tried various innovations to improve government efficiency and enhance its legitimacy (Chew 1990a; Wu 2014). However, as pay levels deteriorated with egalitarianism triumphed, the 1985 remuneration reform based on the previous classification of regions did not achieve its policy goals. Overall, it only had limited impact on the regional variation in civil service pay. The Gini coefficient can be used to show the egalitarianism in income distribution: a smaller Gini coefficient means a more equal distribution. As Fig. 2 shows, the Gini coefficient in the regional civil service pay mostly stayed around 0.1 in the 1985-1992 period, obviously lower than that in the later period.

Eight years after the 1985 pay system was introduced, "The Interim Regulations of Civil Servants" (guojia gongwuyuan zanxing tiaoli) issued in 1993 greatly transformed the structure of civil servants' wages. In addition to the four components of wage, regional and other allowances were introduced into the civil service pay. Furthermore, Treaty No. 74 of the "Civil Servant Law", which governs the pay structure of civil servants, reaffirmed that "civil servant wage is made up of basic wage, allowance, subsidy, and awards". It is worth noting that this allowance consists of "regional additional allowance, allowance in arduous remote areas, position allowance and etc.", and the subsidy comprises "assistance in housing and medical treatment". Since 1993, the wage of each civil servant includes nationally unified regular wage, and allowances and subsidies that differ among regions. Civil service pay then entered an era in which regional variation significantly increased (see Fig. 2).

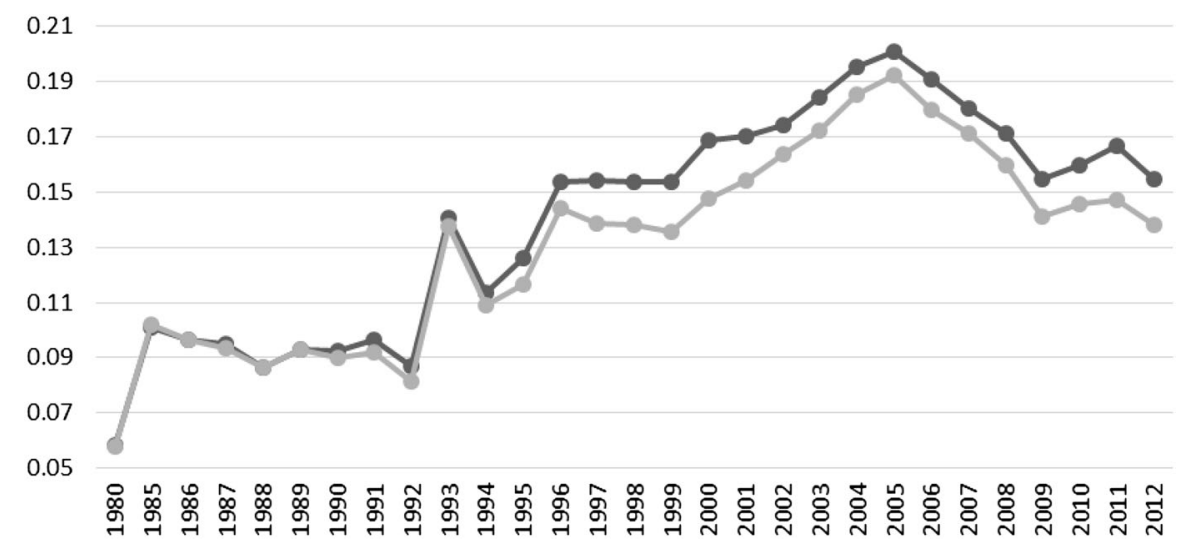

Fig. 2 The Gini coefficient of average government officials' wage (1980-2012). Data Source: National Bureau of Statistics (1987); Chinese Statistical Yearbook (1989-2013). Note: Data from 1980 to 2008 are calculations of the average wage of civil servant staff. Data after 1980 are the average wage of civil servant employed person. Although this difference does not affect the comparison of the income gap; Gini coefficient is counted by Wessa (2014). Since Hainan Province and Chongqing Municipality have not been admitted as a provincial administrative unit, we separate the data into 29 groups from 1980 to 1987; data from 1988 to 1996 did not contain Chongqing Municipality, and thus resulted in 30 groups; in 1993, the data of Yunnan province was absence. The data was divided into 31 groups since 1997 
The adoption of the structural wage system and the increase in regional variation of pay levels mentioned above occurred against the background of economic marketization and decentralization. Economic reforms in the 1980s were in accordance with the idea that the increment was prioritized over the stock. By enlarging increment and freezing stock, the economy was made to grow out of the plan in a gradualist manner (see Naughton 1996). The reform greatly improved income level in those non-public owned sections that were less restricted by the centrally planned economy. Till late 1980s, the phenomenon was vividly described as "selling boiled eggs is better off than building nuclear missiles, and working with a razor blade is better off than with a surgical blade". During the second half of the 1980s, employees of state-owned enterprises that were granted some autonomy in management by and large had an average income approximately $10 \%$ higher than those employed by the national agencies, while the corresponding figure was only $5.5 \%$ in year 1977 (Shi and Wu 1993, 301).

For an extended period of time, the center regarded the civil service pay adjustment as part of the regulatory policy. Since the late 1980s, the center started to irregularly introduce policies specifically aimed at adjusting the wage structure and increasing public sector employment. For example, "the Interim Regulations of National Civil Servants" in 1993 determined that "government should systematically improve the wage standard of civil servants based on the development of the national economy and the changes in the Cost of Living Index, gradually raising the actual wage of civil servants" (Treaty No. 17); "the wage level of civil servants and staff in public ownership section should be roughly fair" (Treaty No. 16). "Decision of Central Committee of Chinese Communist Party and the State Council on Further Strengthening Talent Management" (zhonggong zhongyang guowuyuan guanyu jinyibu jiaqianng rencai gongzuo de jueding) issued in 2004 reaffirmed the goal to "establish such a decision system of wage level that civil service pay is coordinated with development of the national economy, adapt to social advancement, and approximately comparable with the average counterparts in enterprises".

The changes in central-local relationship since the reform and opening up, especially the expansion of local financial decentralization, exerted tremendous influence on the adjustment of the level and structure of civil servants' wages, as well as its regional variation. Unified central control over income and expenditure prior to the 1980s indicated that the local governments had little systematic fiscal and economic policy autonomy. Local governments were mainly the executor of the center, although they were burdened with a large proportion of the responsibility to levy national revenue and public expenditure (like education, sanitation and administrative management) (Wong 2007).

In Mao's era, the remuneration for local civil servants was paid from central allocation, financed by central "transfer payment" or financial appropriation. Within the system, the regional variation of civil service pay was completely regulated by the center through the regional wage classification or ranking, which made the regional variation fairly narrow. As indicated in Fig. 2, in 1980, the Gini coefficient of average wage of local civil servants was less than 0.06 .

The reform and opening up in China, as far as the fiscal system was concerned, began with the abandonment of unified central control over income and expenditure, 
and the adoption of the fiscal contract responsibility system (caizheng baoganzhi) (Montinola et al. 1995). Under this new system, local governments still shouldered most of the responsibility of levying national revenue. However, unlike the unified centrally control system in which almost all the expenses of the local were "appropriated" by the center, fiscal contract responsibility system regulated the central-local fiscal relationship in the form of a contract. The length of the contract was commonly 5 years, within which the allocation of annual revenue between the center and the local, and even among each level of local governments was made according to settled agreement. For instance, in the mature era of fiscal contract responsibility system (1988-1993), the central-local fiscal relationship could first be divided into two types depending on whether the local received additional financial aid from the center. Within 30 provincial-level administrative regions and 5 municipalities with independent planning status that had direct fiscal relationships with the center, 14 were aid receivers. These regions, according to the contract, received quota fiscal subsidy from the center. Furthermore, fiscal revenue collected by provinces themselves, a small ratio of which was turned over to the center, was mainly under their control. In contrast, the rest of the areas turned various proportions of their fiscal revenue over to the center and kept the rest according to the contracts.

Theoretically, under the fiscal contract responsibility system, the Gini coefficient of regional civil service pay is likely to be affected by local financial capability, thus widening the regional inequality of wage levels. However, as demonstrated in Fig. 2, after a soar in 1985, the Gini coefficient remained relatively low till 1992, at approximately 0.10 . In order to explain the phenomenon, we maintain that this observation can be accounted for by three factors. Firstly, before the Speech of the South Cruises (nanxun jianghua) by Deng Xiaoping in 1992, which called for a fullfledged market-oriented reform of the Chinese economy, regional variation in economic performance was still limited. Secondly, the wage system reform of 1985 that continued to be effective until 1992 did not contain any provisions of local subsidy and allowance. As a result, the local governments had little room to maneuver in adjusting formal wages. Thirdly, extra-budgetary revenue increased annually during the period of fiscal contract responsibility system, a fairly large proportion of which was used for welfare rewarding and administrative affairs 5 (Wedeman 2000; Ma 2005; Zhan 2013). However, according to the statistical definition in China, welfare incomes of employees are not counted as remuneration.

The tax-sharing system introduced in 1994 was a reform characterized by both centralization of authority and local decentralization. It represented a centralization of authority because under the current framework, the central government no longer depended on the local branches in collecting tax revenues. The State Administration of Taxation was founded to collect the central tax and the central-local sharing tax,

\footnotetext{
5 For example, in 1990, the sum of extra-budgetary expenses was 270.7 billion yuan, including 34.84 billion for welfare and awards expenditure and 18.71 billion for administrative expenditure. In the same year, the total sum of wage spending on nation-wide civil servants was 19.63 billion, significantly smaller than the extra-budgetary spending on welfare and awards. This is because before 1993, state-owned enterprises were included in the extra-budgetary statistics. Even so, there should be a considerable amount of money spent on extra-budgetary welfare and awards by national agencies.
} 
allowing the central government to occupy a larger proportion than the necessary expenditure requirement to fulfill its responsibility. Therefore, the central government has been capable to exploit the policy instrument of fiscal transfer payment to digest its huge financial "surplus", and in doing so, influence local behavior. On the other hand, the tax-sharing system achieves greater institutionalization in the division of fiscal revenue between the central and the locals. Total national revenue is unambiguously classified as the central revenue, local revenue, and sharing revenue, with sharing revenue allocated according to the preset rules agreed upon between the center and local, and part of the fiscal transfer payment being made according to certain formulations. This arrangement allows for higher degrees of autonomy in local fiscal behavior.

As a result, the level of local civil service pay after the introduction of the taxsharing system is a function of local fiscal revenues and income from central transfer payment. As stated by Li $(2006,63)$, the purpose of the general fiscal transfer payment is to "guarantee the basic public expenditure demand stemming from the salary payment of the staff in national agencies and public-owned sections as well as the cost to run government offices". Besides the regular general fiscal transfer payment, in order to alleviate the lack of domestic demand in the aftermath of the Asian financial crisis, former Premier Zhu Rongji raised the salary of the staff in government agencies and public-owned sections and the pension for retirees for four times during his tenure, in July 1999, Jan. 2001, Oct. 2001, and July 2003. The most recent policy of wage adjustment was announced in July 2006. ${ }^{6}$ According to the policy, provinces in the developed coastal areas are to raise their own funds to finance higher levels of local civil service pay, while provinces located in Northeast Old Industrial Base and the central and western parts of the country could obtain different amounts of subsidies from the Central. Moreover, the central government could provide special financial aid to ethnic-minority areas, and wage adjusting transfer payment was specially established from the central budget for that purpose (see Fig. 3).

Since the mid-1990s, repeated wage increments of civil servants aggravated the regional variation of civil service pay (see Fig. 2). In the next section, we empirically investigate the factors behind the observed differences in the wage levels of Chinese civil servants with panel data and regression analyses.

\section{Data, Variables and Method}

The most comprehensive data of civil service pay by occupations and regions can be found in "Chinese Statistical Yearbook", and total and average wages of the civil service sector are presented under the section of "Public management and Social organizations" (since 2004) or "States organs, Political parties and Social organizations" (before 2004). However, the Yearbook uses two different categories

\footnotetext{
${ }^{6}$ In July 2006, "State Council's Notice about Reform on Civil Servants' Wage System" (guowuyuan guanyu gaige gongwuyuan zhidu de tongzhi) was carried out, which removed the "basic pay" and "seniority pay" and increased the weight on "classification wage".
} 


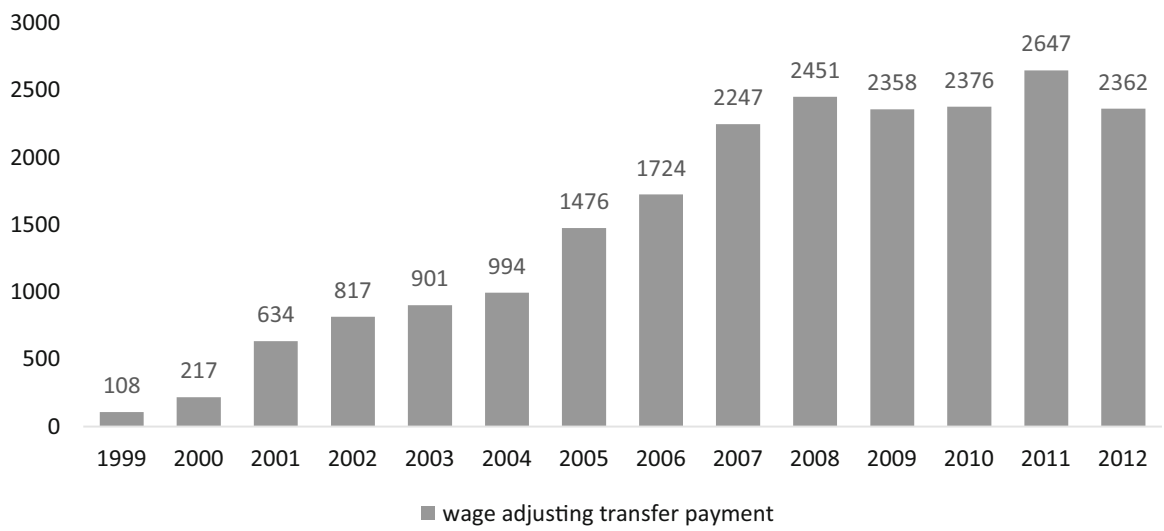

Fig. 3 The annual wage adjusting transfer payment (1999-2012) unit: 100 million. Source: Chinese Fiscal Statistical Yearbook (2008-2013); Li (2010)

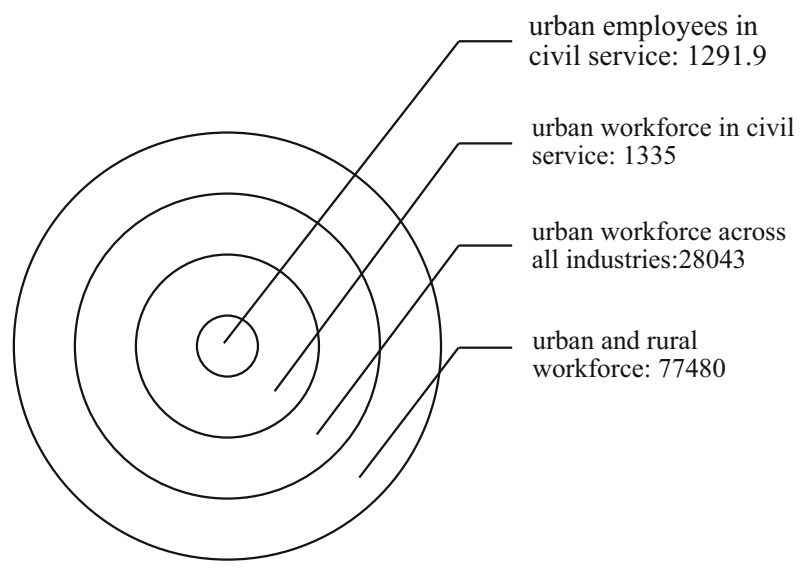

Fig. 4 The scope of study population (2008) unit: ten thousand persons. Source: Chinese Statistical Yearbook (2009)

to present wage data, namely "urban employees" (chengzhen danwei zhigong) and "urban workforce" (chengzhen danwei jiuye renyuan), with the latter covering a wider scope ${ }^{7}$ (see Fig. 4). Further, "Chinese Statistical Yearbook" ceased to report wage data of "urban employees" since 2009, and started to present data of "urban workforce" since 2005. In order to unify the scope of statistics, we use the data of "urban employees" from 1997 to 2008 in our study.

We specify the regression model as follows:

\footnotetext{
7 Actually, based the note of Chinese Statistical Yearbook, "urban employees" excludes urban workforce in private enterprises and township enterprises, the retired, re-employment of the retired, etc. In addition, the category of state organs, political parties, and social organizations may contain the employees at the community level, who may not have a status of civil servant.
} 
Table 1 Descriptive statistics (1997-2008)

\begin{tabular}{lrrrrr}
\hline Variable & $N$ & \multicolumn{1}{c}{ Mean } & \multicolumn{1}{c}{ SD } & Minimum & Maximum \\
\hline Average wages of civil servants (ln) & 372 & 9.575 & 0.610 & 8.435 & 11.157 \\
Per capita fiscal revenue (ln) & 372 & 6.527 & 0.898 & 4.585 & 9.426 \\
Per capita net income of transfer payment (ln) & 372 & 6.449 & 0.915 & 4.594 & 9.805 \\
Dependency on transfer payment (\%) & 372 & 50.592 & 27.301 & 9.088 & 252.451 \\
Officials to population ratio (\%) & 372 & 1.043 & 0.359 & 0.588 & 2.669 \\
Average price of commercial housing (ln) & 372 & 7.570 & 0.530 & 4.883 & 9.546 \\
Per capita GDP (ln) & 372 & 9.210 & 0.730 & 7.654 & 11.231 \\
FDI (ln) & 372 & 6.029 & 1.643 & 1.407 & 9.657 \\
Level of urbanization (\%) & 372 & 32.339 & 15.795 & 13.800 & 87.460 \\
Level of industrialization (\%) & 372 & 45.228 & 8.135 & 19.760 & 61.500 \\
Level of service industry (\%) & 372 & 38.546 & 6.761 & 25.400 & 73.200 \\
Wage adjustment policy & 372 & 0.500 & 0.501 & 0 & 1 \\
\hline
\end{tabular}

Source: Chinese Statistical Yearbook (1998-2009); Chinese Fiscal Statistical Yearbook (1998-2009); Chinese Population and Employment Statistics Yearbook (1998-2009)

Relevant variables are adjusted based on constant price of 2005; FDI is adjusted based on both the exchange rate and constant price

$$
Y_{i j}=\alpha+\beta_{1} Y_{i j-1}+\boldsymbol{\beta}_{2} \boldsymbol{X}_{i j}+\boldsymbol{\beta}_{3} Z_{i j}+K_{i}+F_{j}+\varepsilon
$$

where $\boldsymbol{Y}_{\boldsymbol{i j}}$ denotes civil service pay of province $i$ in year $j$, with $\boldsymbol{Y}_{\boldsymbol{i j}-\boldsymbol{I}}$ being its oneorder lag form; $\boldsymbol{X}_{\boldsymbol{i} j}$ is a vector of political and administrative factors, while $\boldsymbol{Z}_{\boldsymbol{i} \boldsymbol{j}}$ is a vector of economic and market factors. $K_{i}$ and $F_{j}$ are province-fixed effect and year dummies respectively andeis the residual term. Table 1 shows the descriptive statistics of the relevant variables.

For economic factors, we use GDP per capita to measure levels of economic development of different regions. Higher levels of economic development mean richer fiscal resources, which may lead to higher civil service pay. In addition, we take average price of commercial housing as a proxy for living cost: higher housing price usually means higher rent, in which gives rise to higher costs of most fundamental products and raises the cost of living within the region. We hypothesize that levels of economic development and living cost are positively associated with the wage levels of civil servants. Based on the same consideration, we hold a similar hypothesis about the relationship between civil service pay and several other variables such as "level of urbanization" (measured by the urban population share of total population) and industrial structure (measured by the proportion of GDP contributed by secondary and tertiary industries). Besides, as regional distribution of foreign direct investment (FDI) can indirectly affect regional economic growth potential and financial resources, we also take FDI into consideration. On the whole, unlike the centrally planned nature of civil service pay, the movement of FDI is influenced mostly by the market. Specifically, owing to larger regional markets, better infrastructure, stronger technological and innovative 
capability and more significant geographical advantage, economically developed areas tend to attract more FDI, and wage cost had a negative effect on FDI (Cheng and Kwan 2000; Broadman and Sun 1997). Moreover, FDI seems to promote economic growth, and this positive growth effect seems to be stronger in the coastal than the inland regions (Zhang 2001). However, since the growth of civil service pay is not fully a product of the market, the increase of FDI is unlikely to translate into higher civil service pay in the short term. Thus, regional civil service pay and FDI may be either negatively correlated or uncorrelated.

As for political factors, we measure fiscal resources of different regions with "per capita fiscal revenue", namely the main source of civil service non-basic wage. Other things being equal, regions with richer fiscal resources are more likely to pay their civil servants higher wages. Meanwhile, we introduce two other variables to capture the effects of transfer payment: "per capita net income of transfer payment" (local revenue gained from central subsidy minus local revenue turned into the central) and "regional dependence on the transfer payment" (the proportion of net income of transfer payment in the general budgetary expenses). Both variables are expected to be positive related to the level of civil service pay. Ideally speaking, we should make a distinction between "general transfer payments" used to finance the expenditures of civil service pay and "specific purpose transfer payments". However, due to lack of relevant data, this attempt is unrealistic. But even specific purpose transfer payments can influence the wage level of a region's civil service sector because they may be appropriated to pay the civil servants. Conversely, local governments may appropriate the funds designated for civil service pay to support specific purpose transfer payments (Wu 2009, 2011, 2014). We also measure government size using the ratio of civil servants to resident population. Since public administration is by and large a labor-incentive sector, wage expense could be the most critical factor influencing its budget. As a result, holding the overall budget constant, the larger the scale of employment, the lower the wage level, and vice versa (Schiavo-Campo and McFerson 2008). Furthermore, the employment of civil servants is largely controlled the bianzhi system (Brødsgaard 2002), and the financial support for civil service pay is largely allocated based on size of personnel in the bianzhi system. Therefore, changes in civil servant to resident ratio during a particular time frame are very likely to induce fluctuations in civil service pay. Therefore, we expect significant effects of government size on civil service pay. Besides, in order to explore the effect of government policy, we use dummy variables to code policies of wage adjustment. The variable takes value 1 for years following any policy of wage adjustment, and 0 otherwise. ${ }^{8}$

Currency units of all relevant variables are adjusted based on the CPI of 2005. With the exception of transfer payment dependence, level of urbanization, industrial structure and policy dummy variables, all variables are converted to the logarithm form. The estimation methods used are SYS-GMM or Fixed-Effect models (FE). The SYS-GMM requires that the first order difference of deviation is significant in first-order serial correlation and not significant in second-order serial correlation

\footnotetext{
${ }^{8}$ As there were two general adjustments in January and October 2001, the values of year 2001 and 2002 are both coded as 1 .
} 
(Bond 2002). This requirement is well met according to the parameters of ArellanoBond test shown in Table 3 (AR (1) is significant and AR (2) is not); Meanwhile, the parameters of Sargan-test show that the exogeneity of instrumental variables is also met (Model 2 and Model 4-6). However, since the policy models (Table 3) contain some dummy variables, they fail in meeting the requirements of SYSGMM. Therefore, we use fixed effect models for the estimation.

\section{Empirical Results and Discussion}

Tables 2 and 3 report the results of our regression analyses. Table 2 investigates effects of the relevant economic and political factors (except for central wage adjusting policy). Table 3 looks at how central wage policy influences regional civil service pay levels. Since Tibet is so special that the central could provide it with the amount of fiscal transfer payment even larger than its GDP, we purposely drop Tibet from the sample in Model 5 and 6 of Table 2. The results, however, are essentially the same with the models estimated using the full sample.

Several economic factors including per capita GDP, level of urbanization and size of the service industry are significantly and positively related to civil service pay level, just as we have hypothesized above. That is to say, regional variation in the levels of civil service pay reflects the unbalanced nature of economic development, urbanization, industrialization and the development of the tertiary industry. Model 2 and 4-6, estimated using the SYS-GMM, show that other things being equal, FDI has a significantly negative relationship with our dependent variable, which runs against our hypothesis that the concentration of capital demands high-quality civil servants and reinforces their high pay, as previously mentioned. However, the empirical result above indicates an important but often overlooked fact that the mechanisms of the growth of public service pay and the flow of FDI are likely to be fundamentally different. Specifically, although the flow and growth of FDI may be influenced by political factors such as taxes and businessfriendly policies, it is essentially market-oriented (Du et al. 2008), while civil service pay is largely subject to strict policy regulation. Thus, this negative relationship can be most plausibly explained by the different growth mechanisms of FDI and civil service pay, which our initial hypothesis ignores.

Similarly, most political variables also meet expected significance level. Both regional fiscal revenue and transfer payment income are highly significant. Besides, these two variables have similar marginal effects: a $1 \%$ increase in fiscal revenue or transfer payment is associated with about $0.2 \%$ rise in regional average wage level, with the former having a slightly larger effect than the latter. Transfer payment dependence also has a positive effect on the provincial average civil service wage, showing the relationship between the civil service pay and transfer payment is robust. Furthermore, the regression coefficient of official-to-population ratio suggests that average civil service wage would decline with the expansion of government. It is worthwhile to note that a marginal increase in this ratio means numerous new employees entering the public sector. Thus, it is not surprising that the marginal effect of this variable on average civil service pay level is rather 


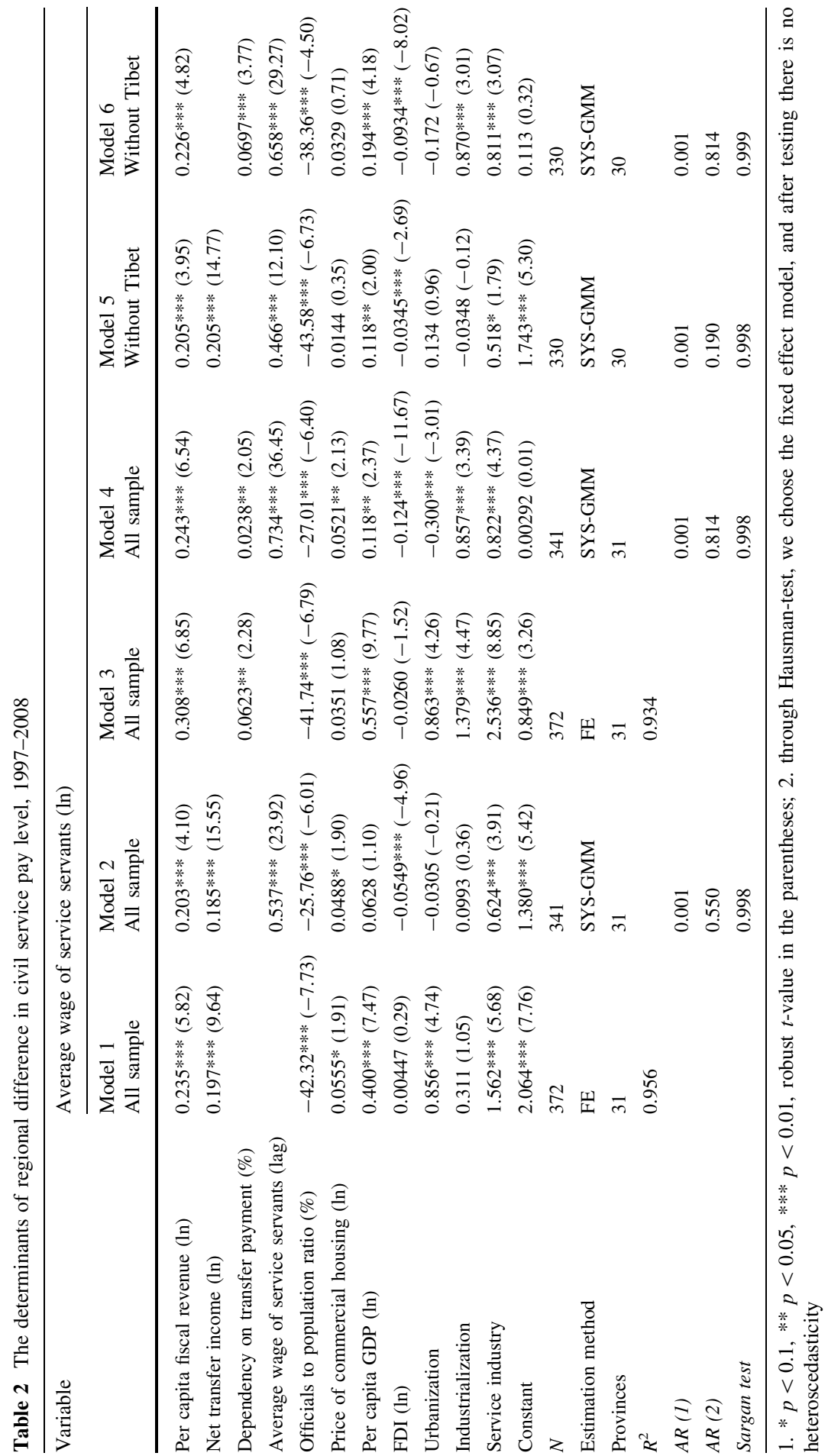


Table 3 Civil service pay level and wage adjustment policy (1997-2008)

\begin{tabular}{llll}
\hline Variables & \multicolumn{4}{l}{ Average wage of service servants $(\mathrm{ln})$} \\
\cline { 2 - 4 } & Model 7 & Model 8 & Model 9 \\
\hline Average wage of service servants $(\mathrm{lag})$ & $0.829^{* * *}(23.93)$ & $0.824^{* * *}(23.78)$ & $0.827^{* * *}(24.01)$ \\
Price of commercial housing $(\mathrm{ln})$ & $0.0605^{* *}(2.20)$ & $0.0526^{*}(1.90)$ & $0.0551^{* *}(2.01)$ \\
Per capita GDP $(\mathrm{ln})$ & $0.195^{* * *}(5.74)$ & $0.205^{* * *}(5.98)$ & $0.200^{* * *}(5.90)$ \\
Urbanization & $0.00280(0.02)$ & $-0.0226(-0.16)$ & $0.00321(0.02)$ \\
Industrialization & $0.0946(0.44)$ & $0.128(0.60)$ & $0.115(0.54)$ \\
Service industry & $0.268(1.21)$ & $0.317(1.42)$ & $0.297(1.35)$ \\
Wage adjustment policy & $0.0408^{* * *}(5.92)$ & $0.0584^{* * *}(5.45)$ & $0.0347^{* * *}(4.70)$ \\
Policy*Central Region & & $-0.0276^{*}(-1.69)$ & \\
Policy*Eastern Region & & $-0.0296^{*}(-1.92)$ & \\
Policy*Minority Area & & & $0.0381^{* *}(2.19)$ \\
Constant & $-0.659^{* * *}$ & $-0.667^{* * *}$ & $-0.661^{* * *}$ \\
$N$ & $(-5.98)$ & $(-6.07)$ & $(-6.03)$ \\
$R^{2}$ & 341 & 341 & 341 \\
Provinces & 0.936 & 0.946 & 0.947 \\
\hline
\end{tabular}

$1 . * p<0.1, * * p<0.05, * * * p<0.01$, robust $t$-value in the parentheses; 2 . through Hausman-test, we choose the fixed effect model, and after testing there is no heteroskedasticity

substantial. Finally, the coefficient of the lagged dependent variable shows that on average, civil service pay level is about 5-7\% higher than in the previous year during the 1997-2008 period. Understandably, this finding suggests the existence of "path dependence" of civil service pay in China. In other words, mainly with policy change on wage adjustment, civil service pay of various regions in a given year grows, from a base, namely the level of civil service pay last year. Also, because of the pressure of public opinion and fiscal pressure, this coefficient indicates the growth of civil service pay in China is in minor adjustments.

Table 3 investigates the effects of the central government's wage adjustment policy on the regional variation of civil service pay. In general, the years following the announcement of wage-raising policies would witness a $4 \%$ increase in the average wage of civil servants compared with the rest of the years. This also means that, strictly speaking, the "administrative type" of wage adjustment is piecemeal in nature, and this finding is in consonance with the explanation of "path dependence" of civil service pay above. This is because the bulk of the funds for wage-raising comes from central finance, which brings about higher financial pressure on the central government if the increase is more substantial. Also, large increments in civil service pay can easily put the central government under huge pressures from public opinion.

In addition, we also investigate the regional disparity of the center's wage adjustment policies by including interactive terms. Model 8 in Table 3 suggest that in the years following wage-increment policies, the remote and poor western areas would enjoy a faster increase of civil service pay, about $3 \%$ higher than the central and 
eastern areas. Moreover, Model 9 shows that civil servants in ethnic minority areas enjoy higher rate of wage increase compared with their counterparts in non-ethnic minority areas. Specifically, civil servants in ethnic minority areas have their wages increasing $4 \%$ faster following the implementation of wage adjusting policies. All these findings support the political logic of central transfer payment (Wang 2002).

Overall, the above findings indicate that even with China's economic fundamentals having reached a relatively high level of marketization, and fiscal decentralization asking for "a level of government with corresponding level of budget"(yiji zhengfu, yiji yusuan), the central can still play a powerful role in deciding civil service pay of the regions. This is generally achieved through both central policy regulation and transfer payment. Since the adoption of the tax-sharing system, the central government has taken somewhere between 50 and $55 \%$ of the national aggregate fiscal revenue, while its expenditure has been reduced from $30 \%$ in 1994 to $21 \%$ in 2008, and further down to $15 \%$ in 2012. All these would mean that the central government has to "digest" the large amount of fiscal income via transfer payment, and that local governments are strongly relying on the transfer payment from central government to cover the expenditure gaps. For example, in 2008, central government allocated about 2295 billion yuan for local tax returns and transfer payment, which constituted $62.48 \%$ of the aggregate revenue of about 3651 billion. Correspondingly, $44.48 \%$ of the total local fiscal revenue (5159 billion), came from tax returns and transfer payments from the central government (see Chinese Fiscal Yearbook, 2009). Such gargantuan transfer expenditure has become the crucial factor in shaping the regional level of civil service pay in China. Moreover, distribution through central transfer payment, especially wage adjustment transfer payment, benefits less developed provinces more.

\section{Conclusion}

In this article, we build a theoretical framework explaining regional variation in China's civil service pay. To that end, we divide possible factors into two groups: political or administrative factors and economic or market factors. In terms of politics, the most important factor is intergovernmental relations and fiscal capability of both central and local governments. In China, national authorities control the size of public sector employment and basic level of regional civil service pay mainly through the bianzhi system and wage adjusting policies. Under the centralization of central fiscal revenue and decentralization of regional fiscal expenditure after reform of the tax-sharing system, there are two main sources for civil service pay: on-budget revenue of local government and transfer payment from upper-level governments, especially from the central government. The former is indirectly influenced by regional economic development, and the latter aims at realizing central political goals and controlling the regional gap of civil service pay. On the other hand, economic factors represent a constraint on central wage adjusting policy and government fiscal behaviors. These factors lay the foundation of regional civil service pay in the long run, and affect the degree and propensity of central wage policy in the short run (e.g., larger amount of fiscal transfer payment to less- 
developed areas). To sum up, since the mid-1990s, regional divergence of Chinese civil service pay has been fluctuating as a result of economic fundamentals constraining government behaviors and governments responding to these constraints. After an overview of the relevant policy changes, we conduct an econometrical analysis of the cross-provincial difference in civil service pay. This theoretical framework is well supported by our empirical results.

Specifically, there are four political determinants in addition to regional economic development and cost of living. First, local governments' fiscal revenue and central government's transfer payment, the main sources of civil service pay, are responsible for the stable growth of the wage in different regions, with the latter having a slightly stronger impact on the cross-provincial difference. Second, the wage level demonstrates a noticeable path dependence, due to the system in which the civil service pay has been strictly regulated and can only rise or fall with reference to the previous period. Third, since government size is largely determined by the bianzhi system (see Brødsgaard 2002), the level of civil service wage is highly elastic with the size of public sector employment. In other words, holding overall budget constant, a slight expansion of government size may cause a dramatic drop in average remuneration in the short run. ${ }^{9}$ Fourth, the wage policy of the central government carries some preferential bias towards economically undeveloped regions and regions inhabited by ethnic minorities.

At the same time, economic fundamentals also influence civil service pay level. The cross-provincial difference is the response of the governments to regional economic factors. On the one hand, all kinds of tax revenues are rooted in economic growth, which has become the primary source of government employee wages. On the other hand, the relatively huge disparity in the living costs in a way legitimizes the substantial regional differences in civil service pay level. What the central government needs to consider, however, is how to keep the gap within an acceptable level, which was one of the major targets in the 2006 wage reform. Under the joint influence of multiple factors, the transmission of "administrative intervention" and "market regulation" may differ among regions too: the western provinces benefits more from the planned reallocation, while the eastern region relies more on the power of the invisible hand.

As far as we can see, if we simply place all the factors that influence crossindustry income level on a spectrum ranging from central planning to marketization, those factors mainly affecting civil service pay are undoubtedly closer to the "central planning" end. Therefore, this paper belongs to a grand theoretical proposition: in a mixed economy like China where government and market forces are separated clearly, how are the income levels of different industries and sectors affected by the control of national authorities, and how do they react to the law of

\footnotetext{
9 It is noteworthy that employees in state organs, political parties, and social organizations may be within or outside of bianzhi system, and the two kinds of employees bring different degree effect to the public service pay in whole due to their different welfare and salary structure. However, there is no other data to distinguish the employees of public sector within bianzhi system and the ones outside this system. Also, setting the size of government as control variable, we do not investigate the relationship between the existence of political factors such as ethnic minority areas, and the size of government. Thus, the conclusion above is general.
} 
the market? These questions are crucial themes of political economy. With this broad picture in mind, we just choose a representative object, namely public service pay in China, to conduct a specific study.

\section{References}

Araújo, B.C., and L.S. Paz. 2014. The effects of exporting on wages: an evaluation using the 1999 Brazilian exchange rate devaluation. Journal of Development Economics 111: 1-16.

Beramendi, P., and T.R. Cusack. 2009. Diverse disparities: the politics and economics of wage, market, and disposable income inequalities. Political Research Quarterly 62(2): 257-275.

Bond, S.R. 2002. Dynamic panel data models: a guide to micro data methods and practice. Portuguese Economic Journal 1(2): 141-162.

Boskin, M.J. 2008. Consumer Price Indexes. In Concise Encyclopedia of Economics, Eds. Henderson, David R (ed.). Indianapolis: Library of Economics and Liberty.

Boskin, Michael J., et al. 1998. Consumer prices, the consumer price index, and the cost of living. Journal of Economic Perspectives 12: 3-26.

Brennan, G., and James M. Buchanan. 1980. The power to tax: Analytic foundations of a fiscal constitution. Cambridge University Press.

Broadman, Harry G., and Xiaolun Sun. 1997. The distribution of foreign direct investment in China. The World Economy 20(3): 339-361.

Brødsgaard, Kjeld Erik. 2002. Institutional reform and the bianzhi system in China. The China Quarterly 170: 361-386.

Burns, John P., and Xiaoqi Wang. 2010. Civil service reform in China: impacts on civil servants' behaviour. The China Quarterly 201: 58-78.

Cooke, Fang Lee. 2004. Public-sector pay in China: 1949-2001. The International Journal of Human Resource Management 15(4-5): 895-916.

Chan, Hon S., and Edward Li Suizhou. 2007. Civil service law in the People's Republic of China: a return to cadre personnel management. Public Administration Review 67(3): 383-398.

Chan, Hon S., and Jun Ma. 2011. How are they paid? A study of civil service pay in China. International Review of Administrative Sciences 77(2): 294-321.

Cheng, Leonard K., and Yum K. Kwan. 2000. What are the determinants of the location of foreign direct investment? The Chinese experience. Journal of International Economics 51(2): 379-400.

Chew, David C.E. 1990. Civil service pay in China, 1955 to 1989: overview and assessment. International Review of Administrative Sciences 56(2): 345-364.

Chew, C., and C.E. David. 1990. Recent developments in civil service pay in China. International Labour Review 129: 773-782.

Child, John. 1995. Changes in the structure and prediction of earnings in Chinese state enterprises during the economic reform. International Journal of Human Resource Management 6(1): 1-30.

Du, Julan, Lu Yi, and Zhigang Tao. 2008. Economic institutions and FDI location choice: evidence from US multinationals in China. Journal of Comparative Economics 36(3): 412-429.

Erickson, C., and Andrea I. 1995. Wage differentials in Italy: market forces, institutions, and inflation. In Differences and changes in wage structures. University of Chicago Press.

Glassner, Vera. 2010. The Public Sector in the Crisis. ETUI Working Paper 2010.07. Available at SSRN: http://ssrn.com/abstract=2264051 or $10.2139 /$ ssrn.22640512.

Gong, Ting, and A.M. Wu. 2012. Does increased civil service pay deter corruption? Evidence from China. Review of Public Personnel Administration 32(2): 192-204.

Hering, Laura, and Sandra Poncet. 2010. Market access and individual wages: evidence from China. The Review of Economics and Statistics 92(1): 145-159.

Kanbur, Ravi, and Xiaobo Zhang. 1999. Which regional inequality? the evolution of rural-urban and inland-coastal inequality in China from 1983 to 1995. Journal of Comparative Economics 27(4): 686-701.

Knight, John, and Lina Song. 2003. Increasing urban wage inequality in China. Economics of Transition 11(4): 597-619. 
Li, P. 2006. zhongguo zhengfu jian caizheng guanxi tujie [Concise illustration of intergovernmental fiscal relations in China]. Beijing: China Financial and Economic Publishing House.

Li, P. 2010. caizheng tizhi jianming tujie [Concise illustration of fiscal system]. Beijing: China Financial and Economic Publishing House.

Ma, Y. 2005. fenshuizhi gaige hou shengji yuansuanwai shouru pengzhang de yuanyin fenxi [The Causal Analysis of Off-budget Inflation in the Provincial Government after Taxation Reformation]. Gonggong guanli xuebao [Journal of Public Management] 2(1): 49-55.

Montinola, G., Y. Qian, and B.R. Weingast. 1995. Federalism, Chinese style: the political basis for economic success in China. World Politics 48(01): 50-81.

Niskanen, WA. 1971. Bureaucracy and representative government. Transaction Publishers.

Naughton, B. 1996. Growing out of the plan: Chinese economic reform, 1978-1993. Cambridge university press.

Ortiz, I, and Cummins, M. 2013. The age of austerity: A review of public expenditures and adjustment measures in 181 countries. Available at SSRN 2260771.

Qian, Yingyi, and Barry R. Weingast. 1997. Federalism as a commitment to perserving market incentives. The Journal of Economic Perspectives 11(4): 83-92.

Sauré, P., and H. Zoabi. 2014. International trade, the gender wage gap and female labor force participation. Journal of Development Economics 111: 17-33.

Schiavo-Campo, S., and McFerson, H.M. 2008. Public management in global perspective. ME Sharpe.

Shi, Jian, and Zhi Wu. 1993. zhongguo guanyuan de gongzi [The Wage of Chinese officials]. Beijing: Gaige Press.

Soskice, David. 1990. Wage determination: the changing role of institutions in advanced industrialized countries. Oxford Review of Economic Policy 6(4): 36-61.

Tiebout, C.M. 1956. A pure theory of local expenditures. The Journal of Political Economy 64(5): 416-424.

Wang, S. 2002. zhongguo caizheng zhuanyi zhifu de zhengzhi luoji [The political logic of fiscal transfer payment in China]. Zhanlue yu guanli [Strategy and Management] 3: 47-54.

Wedeman, A. 2000. Budgets, extra-budgets, and small treasuries: illegal monies and local autonomy in China. Journal of Contemporary China 9(25): 489-511.

Wessa, P. 2014. Free statistics software.Office for research development and education, version 1.1.23-r7, http://www.wessa.net/.

Wong, C. 2007. Can the retreat from equality be reversed? Assessing fiscal policies toward redistribution from Deng Xiaoping to Wen Jiabao. In Paying for Progress: Public Finance, Human Welfare and Inequality in China, Shue, eds. Vivienne, and Christine Wong, 12-28. Routledge.

Wu, Alfred M. 2009. woguo zhengce zhixingzhong de mubiao niuqu yanjiu: dui woguo sici gongyuyuan gongzi gaige de kaocha[Policy Deviations: an Analysis on Chinese Civil Service Pay Reforms]. Gonggong guanli xuebao [Journal of Public Management] 6(3): 32-39.

Wu, AM. 2011. fenquan xia jiquan shifou youxiao: yige gongwuyuan gongzi zhixing de shijiao [Whether is Centralization under Decentralization Effective? A Perspective from Implementing the Civil Service Pay]. Kaifang shidai[Opening Times] (6):71-82.

Wu, AM. 2014. Governing Civil Service Pay in China. NIAS Press.

Yang, D.T. 1999. Urban-biased policies and rising income inequality in China. The American Economic Review 89(2): 306-310.

Zhan, J.V. 2013. Strategy for fiscal survival? Analysis of local extra-budgetary finance in China. Journal of Contemporary China 22(80): 185-203.

Zhang, K.H. 2001. How does foreign direct investment affect economic growth in China? Economics of Transition 9(3): 679-693.

Yu You is a Ph.D. candidate of Department of Political Science in Xiamen University. His research interests focus on intergovernmental relations, Public finance and local governance in China.

Guang Zhang is Professor of Department of Political Science in Xiamen University, and Research Fellow of Center for Chinese Public Administration Research in Sun Yat-Sen University. He is currently working on the administrative cost of local governments in China, and the evolution of the Central Committee of the Chinese Communist Party. 